Lanckriet, S., Derudder, B., Naudts, J., Tesfay Araya, Cornelis, W., Bauer, H., Deckers, J., Mitiku Haile, Nyssen, J., 2014. A political ecology perspective of land degradation in the North Ethiopian Highlands. Land Degradation and Development, in press.

\title{
A POLITICAL ECOLOGY PERSPECTIVE OF LAND DEGRADATION IN THE NORTH ETHIOPIAN HIGHLANDS
}

Sil Lanckriet ${ }^{1 *}$, Ben Derudder ${ }^{1}$, Jozef Naudts ${ }^{2}$, Hans Bauer ${ }^{3}$, Jozef Deckers ${ }^{2}$, Mitiku Haile ${ }^{4}$, Jan Nyssen $^{1}$

${ }^{1}$ Ghent University, Department of Geography, B-9000 Gent, Belgium

${ }^{2}$ K.U.Leuven, Department of Earth and Environmental Sciences, B-3001 Heverlee, Belgium

${ }^{3}$ Wildlife Conservation Research Unit, Zoology, University of Oxford. Tubney House, Tubney OX13 5L, UK

${ }^{4}$ Mekelle University, Department of Land Resources Management and Environmental Protection, Mekelle, Ethiopia.

*Corresponding author. Email: sil.lanckriet@ugent.be

\begin{abstract}
Severe environmental degradation in the north Ethiopian Highlands is amongst others the result of mismanagement, overpopulation and droughts. However, here we investigate the linkages of land degradation with the historical dynamics of the political-ecological system and regional land policies. We performed semi-structured interviews with 93 farmers in eight villages in the Tigray region (North Ethiopia), and conceptualized a political-ecological model of land tenure and degradation changes for the region. Results show that different land policies caused and still cause land degradation in several ways. Interviews reveal that the unequal character of land rights during feudal times played an important role in $19^{\text {th }}$ and $20^{\text {th }}$ century land degradation. In particular, poor farmers were forced to construct their farms on marginal terrains, such as steep slopes in dry areas and marshes in cold and humid areas, increasing the catchment water runoff and degradation. The interviews further suggest that after the Derg regime (1974-1991), environmental conservation strategies were successfully implemented at larger scales. Overall, feudal, Derg, and contemporary land policies have all
\end{abstract}


had impacts on environmental degradation and have left their fingerprints on the physical landscape of Northern Ethiopia.

KEYWORDS: land policy; land tenancy; land degradation; semi structured interview

\section{INTRODUCTION}

Land degradation is the temporary or permanent lowering of the productive capacity of land (UNEP, 1992), and includes deforestation, expansion of cultivation, increasing water runoff and erosion, and soil degradation. In North Ethiopia, the interplays between climatic vulnerability and land use changes caused severe land degradation (Nyssen et al., 2004; Biazin \& Sterk, 2013), as land use changes can induce vulnerability to droughts (Frankl et al., 2011; Frankl et al., 2013; Mekuria et al., 2012). Consequently, land degradation in Northern Ethiopia is partly linked to the rainfall cycles and drought periods, while crop production comes under high pressure from water deficiencies. Attention in the media to famines in Ethiopia has created a popular view of a drought-stricken country, with a tendency towards decreasing annual rain. Further, Machado et al. (1998) concluded that 'climate is the main long term driving factor of environmental change in the region'. Yilma \& Demarée (1995) and Camberlin (1994), in turn, found that the decline of the rainfall in the Sahel observed since about 1965 is also seen to a lesser extent in the north central Ethiopian highlands. However, analyses of time series of annual precipitation, reaching up to $2000 \mathrm{AD}$, both for Addis Ababa and the northern highlands, show that there is no evidence for a long-term trend or change in the region's annual rainfall regime, even though the succession of dry years between the late 1970s and late 1980s produced the driest decade of the last century in the Ethiopian highlands (Conway, 2000). Such 20th century climate variability appears to be linked with several quasi-global teleconnections, such as the Somali jet, El Niño Southern Oscillation, and the Tropical Easterly Jet (Segele et al., 2009a; 2009b). In addition, Cheung et al. (2008) found no significant yearly and seasonal changes in rainfall for the period 19602002 in the region comprising the investigated watersheds in northern Ethiopia. Terwilliger et al. (2011) showed, based on their paleoenvironmental study on gully walls, that the Ethiopian kingdoms after $800 \mathrm{AD}$ were not exposed to general changes in climate. Furthermore, Nyssen et al. (2004) found that climate alone cannot explain the widespread land degradation. They argue that many phenomena that have been interpreted as climate-driven can as well be of 
anthropic origin. Thick sediment deposits on pediments and increase of secondary forest, scrub and ruderal species in pollen diagrams prove this human impact.

In absence of a clear drying trend, land degradation is presumably linked with drought vulnerability of lands suffering from a heavy human impact. From this perspective, Girma Kebbede \& Jacob (1988) claim that internal political contradictions and other political factors have a commanding impact on environmental degradation and famine in the Highlands. According to Ståhl (1974) and Ståhl (1990), the problem of land degradation in northern Ethiopia is eventually a political one. However, while political ecology has emerged as a top level research field for explaining land degradation (Blaikie, 1985; Andersson et al., 2011; Krings, 2002; Benjaminsen et al., 2010), no comprehensive framework for explaining land degradation from political-ecological perspectives exists for the Tigray Highlands. Hence, in this paper we hypothesize that degradation in the Tigray Highlands can, in addition to the effects of land use changes and climate vulnerability, be related to changes in the politicalecological system and related land policies. Using semi-structured interviews with local farmers, the paper examines i) the impact of feudal political-ecological systems and land policies, and ii) the impact of contemporary political-ecological systems and land policies on land degradation processes.

\section{MATERIALS AND METHODS}

\section{The study area at macro-scale}

The Northern Ethiopian Highland is home to one of the oldest agrarian societies of Africa, as the region is known as one of the heartlands of the Neolithic Revolution (Roberts, 1997). During the Abyssinian Empire (until 1974), society was organized in a feudal and highly unequal way. Local noblemen, such as dedjazmach, held ultimate power over the lands (Bruce, 1976). After the end of the feudal era in 1974, a military junta (DERG) was installed, but their land reforms (an overall nationalization of farmlands with strong state control of the farms) were only partially implemented in Tigray. After the overthrow of the DERG regime in 1991, the Tigray People's Liberation Front (TPLF) initiated a huge land redistribution, so that all households received - generally speaking - three farm plots. However, lands are still often lent out in a sharecropping system, locally named mwufar, consisting of a temporary transfer (normally for the duration of one agricultural season) of the use rights of a plot of 
land in exchange for a share of the grain harvest (Segers et al., 2010). Since the 1990s, important conservation efforts (check dams, stone bunds, reforestation) were made and agricultural intensification was enhanced (e.g. improved crop varieties, chemical fertilizers). Still, overgrazing of rangeland is a particular problem in the highlands, as current stocking rates are well in excess of estimated optimum stocking rates (Nyssen et al., 2004).

\section{Semi-structured interviews}

During two fieldwork campaigns, 93 semi-structured interviews (below coded with one or two letters) were performed in several villages. A first campaign was carried out in AprilAugust 2002 (Naudts, 2002), and included 14 (semi-)structured interviews with keyinformants (KI) in the villages of Adi Kolkual, Adi Hantatzo, Hara, Guwa, Dingilet, T'ashi and the town of Hagere Selam. The interviews focussed on older farmers, priests, and administrative staff; and additionally on 39 farmers in Hechi and Agerba. During a second campaign in December 2012, forty farmers were interviewed in seven villages, May Bati (MB; 8 interviews), Adi Shuho (AS; 5 interviews) May Mekden (MM; 7 interviews), Nebelet (N; 5 interviews), Sinkata (S; 6 interviews), Ashenge (A; 2 interviews) and Lahama (L;7 interviews); (Figure 1). Some additional interviews were performed with the chairman of the Bureau of Agriculture (Hagere Selam), and several village leaders.

All informants were interviewed independently and individually. During two-day walks through the village and its surrounding fields, the farmers were asked targeted questions, and they were invited to show and locate the phenomena they were talking about. Only if all interviewed farmers in one village came independently and individually to the same insights, these insights were used in the study. Care was taken to ensure that if one or more of the interviewed farmers were giving statements that were inconsistent with statements by other farmers in the village, no answers and insights of the farmers in this village were used. The results of this study are therefore only mentioning consistent insights of individually interviewed farmers in a certain village. The method forms thus an adaptation of the AGERTIM technique introduced in the study area by Nyssen et al. (2006) and relates to the Participatory Rural Appraisal techniques (Bryceson et al., 1981; Young \& Hinton, 1996). This method is however based on independent individual interviews instead of group interviews and cannot be labelled 'participatory' since there is no two-way reciprocity.

Key persons and farmers were asked open questions concerning the key characteristics of the rural society, and historical relations between the environment (biophysical, political and 
socio-economical) and the state of the agricultural practices (starting from 1950). As such, questions were asked concerning:

(i) The land distribution during feudal times - and the evolution towards today; e.g. Where were the croplands located? Where were the larger parcels located? etc.

(ii) The land tenancy system during feudal times - and the evolution towards today; e.g. Who owned which parcels? Who rented parcels? Who were the noblemen? etc.

(iii) The land degradation during feudal times - and the evolution towards today; e.g. Were the gullies more active than today? Were there conservation measures? etc.

Given the ages of the interviewed people, such method can produce reliable results up to the 1940s - none of the interviewees could inform about the period before the Italian occupation (1936-1941).

\section{The study area at micro-scale: the example of Hechi}

As an example of a 'typical' rural village, the village of Hechi is discussed below. Hechi is located at an altitude of approximately $2200 \mathrm{~m}$, and is only accessible on foot. The village is located in the district of Dogua Tembien, approximately $4 \mathrm{~km}$ east of the district town Hagere Selam. Here, villages are situated in two main agro-ecological zones in the valley: a low-lying calcareous zone and an upper-lying basalt zone. Hechi is representative for the catchment, since the village lands are situated both at the lower calcareous agro-ecological zone and at the upper basalt agro-ecological zone. The evolution of the village since the 1950s has been studied intensely by Naudts (2002). It has an area of 500-600 ha and has around 200 houses with approximately 1000 inhabitants. Most farmers own some cattle (notably oxen), grazing freely over most lands during the dry season (October till March). Cattle provide traction while ploughing, but produce also milk, meat and manure. Furthermore, cattle function as a saving buffer for times of extreme drought; and can be considered as a status symbol (Naudts, 2002).

An average rural household in the village owns approximately 5 goats and 1 donkey. They own or rent on average $0.75-1.2$ ha cropland, with $60 \%$ of the households having less than 1 ha. All cropland (commonly cultivated with wheat, barley, hanfez, which is wheat and barley sown together, and Eragrostis tef) is ploughed with the local ard plough or mahresha. In Hechi, about half of all farmers own only one ox. Since one ox is not sufficient to use the 
mahresha, two neighbours have to share their oxen, although traction can come from a cow or donkey too (Naudts, 2002).

\section{Conceptual political-ecological model}

In order to conceptualize the different degradation periods since the 1940 s, each period will be considered as a 'political-ecological layer', superimposing previous layers, an approach similar to 'the geological metaphor theory', developed by Doreen Massey. According to Massey (1984), the structure of local economies can be seen as a product of the combination of 'layers' of the successive deposition of new waves of investment. Hence, the contemporary Tigrayan physical landscape can be read as a historical product of the combination of successive layers of economic activity and conservation policies. Each 'layer' has its own political power groups, its own way of producing agricultural goods, its own social relations, and its own inherited environment, all resulting in different kinds of environmental degradation and environmental conservation. Three-dimensional block diagrams will be used to conceptually model the landscape in each of the periods.

\section{RESULTS}

Based on the interview results and Massey's (1984) 'geological metaphor', a conceptual political-ecological model for landscape evolution was constructed using three block diagrams (Figure 2). Notably, three main 'political-ecological layers' would be i) the feudal era (before the start of the civil war in 1974); ii) the Derg and civil war period, coinciding with a major drought; and iii) the post-war period (after 1991). These three eras correspond well with the successive hydrogeomorphic phases in North Ethiopian gully systems, identified by Frankl et al. (2011).

\section{Land policy - degradation nexus during the feudal era (1940s-1974)}

In this period (1950-1974), the croplands were mainly situated at the flatter low-lying areas (MB, L; 2012). Between the parcels, some vegetation and trees were present (KI, 2002; L, MB; 2012). As from 1930, the eucalyptus tree was introduced in the landscape (KI, 2002). All lands were principally owned by the emperor (KI, 2002). According to the interviews (N, 
MB, MM, L, A; 2012), noblemen (dejazmach, meaning 'commanders', a title granted for life) had superior power in the villages; with notably strong power for the 'king' of a village, locally named tikashum. Noblemen owned lands (rist lands) by the approval of the Crown and these rist lands were attributed to 'the first occupiers', and then transferred to their heirs. These rist lands were often lent out in a sharecropping system (Thomas et al., 1991), locally named mwufar or tefurti (KI, 2002; MB, N, L, 2012). Other rist lands were not lent out, and can be considered as 'pure rist' lands (MB, N, L, 2012). Hence, several interviewees (KI, 2002; Table I) indicate that there were four main types of land rights: i) about one third of the lands were used in pure rist; ii) about one third of the lands were rist lands lent out in tefurti; and iii) the rest of the lands were owned by the orthodox church; or iv) direct property of local noblemen ('lands of the Crown'). However, lands of the Church and the Crown could also be rented out in mwufar or laboured by paid day labourers.

Simultaneously, there was an important power synergy between the Orthodox Church and the village tikashums, as tikashums were chosen by the orthodox priests of the village (MB, MM, $\mathrm{L}, \mathrm{N} ; 2012$ ). In all examined villages, one tikashum ruled the village, except for the village of Adi Shuho, where four tikashums rotated every 1-3 years (AS, 2012). The latter might be a system that originates from the Oromo culture more to the south (Melbaa Gadaa, 1988).

The land inequity is a clear reflection of the social inequity during the feudal era. According to most of the interviewed farmers (N, A, L, MB, MM, AS, 2012), social inequity was very high during the feudal time. Twenty farmers stated that the poor had to rent from the rich, and they had to give up to one third of their yield (KI, 2002; N, A, L, MB, MM, AS, 2012). The poorest of all farmers could only survive as day laborers (MB, N; 2012). When asked to describe the economic equity during the feudal era, several farmers replied that $60 \%$ of the farmers were very poor, $30 \%$ were medium poor, and $10 \%$ were very rich. Lahama seems an exception, as five farmers there stated that $95 \%$ of the farmers were very poor, while $5 \%$ were very rich. The impact of the unequal economic power is well reflected in the estimates of land tenancy during feudal times (Table I).

According to the interviews, this unequal character of land rights during feudal times must have played an important role in 19th and early 20th century land degradation. Two mechanisms were identified that mediated such a relationship between land tenancy and degradation. Firstly, farmers stated that most lands, notably the larger, low-lying and level parcels, were owned by noblemen (ristholders) assumed to be descendants of the founders of 
the village or by the orthodox church (L, N, S, MM; 2012). Wealthier aristocrats generally took advantage of their superior political and market power to ensure initial access to better quality resources, as conceptualized by Barbier (1997). These large lands are the rist lands that were lent out in the sharecropping system mwufar (MB, MM, N, L, 2012). Sharecropping renters are less likely to make long-term investments, increasing the degradation (Clay et al., 1994; KI, 2002)). This insecure land tenure has most probably reinforced the tendency towards short-term time horizons in production decisions, and may have biased land use decisions against long-term land management strategies (Barbier, 1997; KI, 2002).

Secondly, interviewees state that inhabitants without genealogical relations to the founding families, and without resources to enter into sharecropping contracts, had no land rights (KI, 2002). They were forced to farm land on steep sloping and marginal terrains (KI, 2002; N, L, MM; 2012). Hence, not only population pressure, but also social inequality, would have induced an upslope extension of farming activities, inducing degradation at these highly erodible (steep) locations. This was notably observed in the village of Nebelet, where the interviewed farmers state that during the Haile Selassie era (before 1974), there were farmlands above at the cliff, cultivated by very poor farmers. More downslope, there was bareland, and even more downslope, there were flatter farmlands of the Church, and the rist lands (N, 2012). This land structure can also be seen on the oldest aerial photograph available for the study area (Figure 3; 1935), acquired by the 7a Sezione Topocartografica during the Italian occupation of Ethiopia (Nyssen et al., 2013).

Interviewees pointed at two main mechanisms for an upslope extension of croplands during the feudal era (an extension by 'poor' farmers, and an extension by 'rich' farmers), depending on agro-climatological conditions. In both cases, due to inferior economic power, the poorer farmers had only access to the more marginal lands. Firstly, farmers in Lahama and May Mekden state that the downslope plots were perceived as 'the most fertile', with more moisture and closer to the houses of the village. Consequently, interviewees state that richer farmers acquired access to these lands (L, MM, 2012). For example in Lahama, the interviewees state that the lowlying irrigated lands were owned by the Church during feudal times (Figure 4). Simultaneously, they state that the more upslope lands were managed in rist and by poor farmers, and these lands extended more upslope over time (L, 2012). These villages are located at relatively low altitudes (Figure 1), with hotter and dryer conditions. In contrast, a second extension mechanism was identified in Adi Shuho, which is located at much higher altitudes (Figure 1), with colder and wetter conditions. Here, farmers stated that 
notably the downslope lands were cultivated by poorer farmers, because it was a marshy area (Figure 4). The upslope lands were perceived as more fertile, because they were not marshy, less ploughed and less grazed since they are located further from the village. In Adi Shuho the richer farmers probably occupied the lower slopes (being warmer than the valley bottoms; Figure 5). These lands equally extended more upslope over time, and were owned by the Church (AS, 2012).

Consequently, land degradation is ancient, since most of the trees and shrubs between the fields and on steep slopes have been cleared during the 19th and 20th century, thereby increasing runoff and soil erosion (French et al., 2009). Some small gullies existed (L, AS; 2012) and periodically, the northern part of the Highlands knew drought periods and famines (1910 - 1913, 1958 - 1959, 1966, 1973 - 1975) (Pageau, 1989; Pankhurst, 1986). However, during feudal times, traditional conservation practices did exist, as the daget system (lynchets) provided some geomorphic protection (Nyssen et al., 2000). At the same time, farmers traditionally had strategies of survival during difficult periods (eg. seasonal migration, church assistance and help from local noblemen; MB, 2012). However, there was no centrally coordinated implementation of conservation policies (KI, 2002). Hence, the politicalecological system of 1950-1974 was of a feudal origin, in a society with different social classes (farmers without lands, ristholders, descendants of the village founder, ...). A lack of centralized conservation policies together with an increased vulnerability to droughts (expansion of croplands) then led to extreme land degradation in the 1970s (Munro et al., 2008), exhausting the agricultural system and amongst others contributing to the collapse of the imperial government (KI, 2012).

\section{Land policy - degradation nexus during the DERG and civil war (1974-1991)}

After the fall of the Haile Selassie regime in 1974, a military junta (DERG) was installed with Soviet support, but their land reforms (nationalisation of all farms and land redistribution to all households) were only partially implemented in Tigray (KI, 2002). From 1979 onwards, the Tigray People Liberation Front started a civil war against the DERG government. The Dogua Tembien district was located in the front zone of the war, with detrimental consequences for the agricultural economy (KI, 2002). For example, the market at Hagere Selam was not accessible for months, production stagnated, and land rights became insecure 
(KI, 2002). Furthermore, a severe drought (1979-1984) struck the country (Mattsson \& Rapp, 1991). Together with the degraded environmental situation inherited from the imperial period, this led to a new and even worse famine (1984) that harassed the region (KI, 2002). Such results are in line with the findings of Kiernan (2013), who showed that proxy conflicts during the Cold War were bringing substantial damage to the physical landscape.

This resulted in a second historical degradation period, after the 1960s, when farmers were confronted with severe soil erosion (Frankl et al., 2011). Yet, already from the late 1970s onwards, some soil and water conservation efforts were undertaken in those areas under control of the TPLF (Munro et al., 2008). However, Munro et al. (2008) conclude from their historical photo monitoring study that the Highlands of Ethiopia had become progressively exhausted. There were "high rates of soil erosion; widespread destruction of the natural vegetation; little thought given to any rehabilitation of land or its cover; runoff was rapid and destructive; and the diminishing returns on agricultural production were leading the country on a downward spiral of degradation" (Munro et al., 2008). For instance the famine of 1984 resulted from the consequences of the civil war, combined with failed yields and severe land degradation during a drought period (KI, 2002). During 1982 and 1983, many farmers in the Highlands didn't even plant crops on their croplands due to military activity and a lack of proper seed material (KI, 2002). As the interviews proved, this land degradation can amongst others be attributed to the economic stagnation during the civil war (KI, 2002), and the land degradation inherited from the feudal period (N, 2012).

\section{Land policy - degradation nexus during the TPLF government (from 1991 onwards)}

After the fall of the DERG regime in 1991, the new government initiated a substantial Structural Adjustment Programme (SAP), supported by the World Bank and the International Monetary Fund (Milas \& Latif, 2000). During this era, focus was put on liberalization, participatory governance and development thinking (Milas \& Latif, 2000). However, we observed that subsistence farming persists in the study area. This is in line with the $65 \%$ of all Tigray household poverty that is chronic, while 35\% is transitory (Fredu Nega et al., 2010). Also, we observed that in the study area more than $90 \%$ of the population lives from agriculture, and farmers' crop yields range from 500 to $1500 \mathrm{~kg} \mathrm{ha}^{-1}$ (KI, 2002). Farmers who have only one ox generally rely on the food relief programme and particularly on food for work (KI, 2012). 
In the post-war political-ecological system, land policies were substantially reorganised. After the victory by TPLF, the new regime organized a new land reform in 1991. Economic equity improved significantly, since agriculture was intensified (amongst others through the introduction of irrigation and fertilizers) and all farmers received a similar amount of land (generally three farm plots); (S, MB, N, A; 2012). A policy named 'Conservation-based Agricultural Development Led Industrialization' was introduced by the government. Soil and water conservation became implemented at large scales, leading to reduced soil erosion rates (Munro et al., 2008; Adimassu et al., 2013). The reforms were predominantly led by the district offices of the Ethiopian Ministry of Agriculture and influenced by guidelines of the World Bank, the United Nations System and the International Union for the Conservation of Nature (Tadesse Kidane-Mariam, 2003). Also NGOs were involved in the on-the-ground implementation of the conservation policies (Kumasi \& Asenso-Okyere, 2011). Tasesse Kidane-Mariam (2003) describes these reforms as a 'technocratic, state-centered management strategy framework based on population control, poverty reduction, sustainable development, and capacity-building'. For instance, the massive implementation of food for work programmes allows farmers to work in infrastructure projects during the dry season in exchange for food distribution (Fredu Nega et al., 2010). Hence, the combination of egalitarian land rights with effective implementation of soil and water policies resulted in decreased land degradation (MB, MM, N, S; 2012), which is registered by remote sensing (de Mûelenaere et al., 2013; Kassa Teka Belay et al., 2014), repeat photography (Nyssen et al., 2009) and by changing gully activities (Frankl et al., 2011).

\section{DISCUSSION}

No attempt for explaining land degradation from a political-ecological viewpoint existed for the Tigray Highlands. Commonly, land degradation has been viewed as the result of overexploitation of natural resources or overpopulation. Some argued that land degradation in the Highlands is generally resulting from the abuse of natural resources by the land users and farmers. For example, Taddese Girma (2001), strikingly neglecting all conservation efforts done over the last decades, states with reference to land degradation in Ethiopia that "(a)doption of soil and water conservation measures has been very limited. Knowledge among farmers about integrated soil conservation and water and nutrient management measures is very low. Tree planting by farmers for fuel and woodlots is declining due to unconfirmed 
private land ownership". However, our interviews showed that knowledge on soil and water conservation among farmers is not low at all. Currently, huge conservation efforts (such as exclosures and stone bunds) are made, and even during the feudal time, the daget system provided soil erosion control. This daget system was quite effective (Nyssen et al., 2000). Partly as a result of this effectiveness, soil degradation before the 1970s was not as severe as during the 1970-1980s. For example, Frankl et al. (2011) show that ephemeral river systems were quite stable during the pre-1970 period. In contrast, the interviews indicate that the feudal land tenure plays an important role, rather than mismanagement by the farmers. According to Stocking (1995), the main features of the mismanagement hypothesis are i) the identification of an environmental problem through selective use of measurements; ii) conceptualising the blame for the problems in terms of ignorance and lack of education; iii) and determination of technical solutions of soil and water conservation or changes in land management practices. However, according to Berg (1992), this view completely denies the huge indigenous knowledge in the study area on environmental resource management in the Ethiopian Highlands.

Furthermore, since the 1970s, some research focussed on the harmful consequences of rapid population growth (Meadows et al, 1972). Modern population growth is assumed to result in accelerated soil erosion due to progressive change in land cover (Wøien, 1995, Tekle Kebrom \& Hedlund, 2000). Notably in developing countries, the overpopulation hypothesis is a popular degradation explanation (Stocking, 1995). Hence, under comparable biophysical conditions, more degraded areas should be found in highly populated regions (Grepperud, 1996). However, there is convincing evidence that areas with high population pressure and market access can be centres of innovations and land care practices (Tiffen et al., 1994). High population density is not necessarily related to land degradation; it is what a population does to the land and the regulatory frameworks installed that determine the extent of degradation (Mitiku Haile et al., 2006; Lemenih et al., 2013). Clearly, our interviews show that current conservation efforts are resulting in reduced soil erosion rates, although population increased over that time. People can be a major asset in reversing a trend towards degradation. Keyzer et al. (2001) attempted a detailed national assessment of soil degradation in Ethiopia. Their study showed that soil degradation has an impact on soils of lower fertility and where population density is low. Hence, the overpopulation hypothesis can hardly be validated as overall low population densities existed through the whole historical period of 19th and early 20th century, when land degradation occurred (Nyssen et al., 2009). 
Such degradation explanations are often presented in a sensational way. For example, Tekle Kebrom stated in 1999 for a region in North Ethiopia that 'unbalanced utilization of forest resources for any use may lead to total degradation of the land in the year 2010' (Tekle Kebrom, 1999), while instead an increase of woody biomass is observed during this period (Nyssen et al., 2009). The interview results presented here consider land degradation as a complex web of political-ecological interactions, rather than a simple or sensational depletion of resources. Moreover, the identified political-ecological eras correspond remarkably well with the main periods of environmental degradation in the region (Frankl et al., 2011): a stable but exhausting pre-1970 environment (with stable gullies); a degrading environment 1970-1990 (with enhanced gully activity); and an improving environmental situation post1990 (with stabilizing gullies).

The political-ecological complexity can be further illustrated by the environmental impact of the exceptional feudal land tenure of chigurafgwoses or shehena, observed in some parts of Tigray and Eritrea before the DERG came to power. In chigurafgwoses, the lands were equally distributed to all farmers in the village. Contrary to the insecure and unequal rist system, chigurafgwoses created incentives for environmental management since "one loses his land if it is neglected, to the contrary of what happens in the case of rist property where rights are not lost in case of land abandonment or neglect" (Nadel, 1946). Finally, for places all over Africa, a growing number of studies are focusing on the effects of land tenure, land ownership and land policies on land degradation (Mastewal Yami et al., 2013; Lestrelin \& Giordano, 2007; Bennett et al., 2012; Glover \& Elsiddig, 2012). In these studies, ineffective land policies are considered as a substantial cause of land degradation, covering a range of tenure systems from neoliberal (Klepeis \& Vance, 2003), communist (Shmelev, 1991; Stringer \& Harris, 2013) to feudal (Moore, 2002) or insecure (Tenge et al., 2004) systems. Political ecology provides an appropriate analytical framework, as it analyses land degradation "from an actor-oriented perspective in the context of unequal power relations, resulting from political decisions, actions and omissions on different levels of action" (Krings, 2002). On a broader level, such a framework is equally valuable for the analysis of land degradation worldwide (Warren, 2002; Robbins, 2012; Zhao et al., 2013; Fleskens \& Stringer, 2013), or for analyzing global environmental problems in general, including deforestation, the loss of biodiversity, desertification and climate change (Adger et al., 2001; Peet el al., 2010). 


\section{CONCLUSIONS}

Land degradation in the North-Ethiopian Highlands should not only, or even mainly, be thought of as the result of mismanagement, overpopulation or for technical-environmental reasons; but is structurally inherent to the political-ecological system and its related conservation policies. Cycles of land degradation seem to correlate well with changes in the land policies, as three main historical political eras were identified: i) the late feudal era, ii) the wartime era, and iii) the post-war era. Indeed, traditional feudal, civil war, and post-war conservation policies follow each other successively. Firstly, the feudal land system could cause land degradation in several ways. Notably, the mwufar sharecropping system discourages sharecropping renters to make long-term investments, especially in environmental conservation. Further, the interviews showed that the unequal character of land rights during feudal times played a role in the $19^{\text {th }}$ and early $20^{\text {th }}$ century land degradation. In particular, farmers 'without lands' were forced to farm at steeper slopes; and rich farmers (or the Church) cultivated their lands away from marshy areas. The existence of some widely implemented conservation structures (such as dagets) indicates that knowledge on soil management existed. Secondly, severe land degradation during the eighties coincided with the civil war, resulting in economic decline and a lack of conservation efforts. Thirdly, the recently observed reduction of soil erosion and sediment yields shows that, despite the increased population pressure, the new conservation efforts and equal land rights succeeded in slowing down the land degradation processes. Finally, while adding a political-ecological framework to the Ethiopian land degradation debate, this paper emphasises the principal role of environmental policies and land ownership in contemporary environmental change.

\section{ACKNOWLEDGEMENTS}

This study would not have been possible without the enormous support, friendship and help of our translators Seifu Kebede and Yohannes Gebregziabher, the support and kindliness of the many farmers who were willing to participate in the interviews, the friendship and help of Lys Moulaert, the support and material assistance of the Belgo-Ethiopian VLIR MU-IUC programme, and a travel scholarship of Ghent University (BOF).

\section{REFERENCES}


Adger N, Benjaminsen T, Brown K, Svarstad H. 2001. Advancing a Political Ecology of global environmental discourses. Development and Change 32: 681-715.

Adimassu Z, Mekonnen K, Yirga C, Kessler A. 2013. Effect of soil bunds on runoff, soil and nutrient losses, and crop yield in the Central Highlands of Ethiopia. Land Degradation and Development. DOI: 10.1002/ldr.2182

Andersson E, Brogaard S, Obsson L. 2011. The Political Ecology of Land Degradation. Annual Review of Environment and Resources 36: 295-319.

Barbier E. 1997. The economic determinants of land degradation in developing countries. Philosophical Transactions of the Royal Society of London Series B: Biological Sciences 352 (1356): 891-899.

Benjaminsen T, Aune J, Sidibe D. 2010. A critical political ecology of cotton and soil fertility in Mali. Geoforum 41 (4): 647-656.

Bennett J, Palmer A, Blackett, M. 2012. Range degradation and land tenure change: insights from a released communal area of Eastern Cape Province, South Africa. Land Degradation and Development 23 (6): 557-568.

Berg T. 1992. Indigenous Knowlegde and Plant Breeding in Tigray, Ethiopia. Forum for Development Studies 19 (1): 13-22.

Biazin B, Sterk G. 2013. Drought vulnerability drives land-use and land cover changes in the Rift Valley dry lands of Ethiopia. Agriculture Ecosystems \& Environment 164: 100113.

Blaikie P. 1985. The Political Economy of Soil Erosion in Developing Countries. Longman, London.

Bruce JW. 1976. Land reform planning and indigenous communal tenures: a case study of the tenure 'chiguraf-gwoses' in Tigray, Ethiopia. PhD thesis University of Wisconsin, Madison, USA.

Bryceson D, Manicom L, Kassam Y. 1981. The methodology of the participatory research approach. In Research for the People, Research by the People: Selected Papers from the International Forum on Participatory Research in Ljubljana, Yugoslavia, 1980, Erasmie T, de Vries J, Dubell F (eds) Linköping University: 94-109.

Camberlin P. 1994. Les précipitations dans la Corne orientale de l'Afrique: climatologie, variabilité et connexions avec quelques indicateurs océano-atmosphériques. $\mathrm{PhD}$ dissertation, Université de Bourgogne 379 pp.

Cheung W, Senay G, Singh A. 2008. Trends and spatial distribution of annual and seasonal rainfall in Ethiopia. Int J Climatol 28: 1723-1734. 
Clay D, Guizlo M, Wallace S. 1994. Population and land degradation. The Environmental and Natural Resources Policy and Training Project, Michigan State University Press, East Lansing, USA.

Conway D. 2000. Some aspects of climate variability in the North East Ethiopian highlandsWollo and Tigray Sinet. Ethiopian Journal of Science 23 (2): 139- 161.

de Mûelenaere S, Frankl A, Haile M, Poesen J, Deckers J, Munro N, Veraverbeke S, Nyssen J. 2013. Historical landscape photographs for calibration of Landsat land use/cover in the Northern Ethiopian Highlands. Land Degradation and Development. DOI: $10.1002 / \mathrm{ldr} .2142$

Fleskens L, Stringer L. 2013. Land management and policy responses to mitigate desertification and land degradation. Land Degradation and Development. DOI: 10.1002/ldr.2272

Frankl A, Nyssen J, De Dapper M, Mitiku Haile, Billi P, Munro RN, Deckers J, Poesen J. 2011. Linking long-term gully and river channel dynamics to environmental change using repeat photography (North Ethiopia). Geomorphology 129 (3-4): 238-251.

Frankl A, Poesen J, Scholiers N, Jacob M, Haile Mitiku, Deckers J, Nyssen J. 2013. Factors controlling the morphology and volume (V) - length (L) relations of permanent gullies in the Northern Ethiopian Highlands. Earth Surf Process Landforms, online early view.

Fredu Nega, Mathijs E, Deckers J, Mitiku Haile, Nyssen J, Tollens E. 2010. Rural poverty dynamics and impact of intervention programs upon chronic and transitory poverty in northern Ethiopia. African Development Review 22 (1): 92-114.

French C, Sulas F, Madella M. 2009. New geoarchaeological investigations of the valley systems in the Aksum area of northern Ethiopia. Catena 78 (3): 218-233.

Girma Kebbede, Jacob M. 1988. Drought, famine and the political economy of environmental degradation in Ethiopia. Geography 318: 65-70.

Glover E, Elsiddig E. 2012. The causes and consequences of environmental changes in Gedaraf, Sudan. Land Degradation and Development 23 (4): 339-349.

Grepperud S. 1996. Population pressure and land degradation: the case of Ethiopia. Journal of Environmental Economics and Management 30: 18-33.

Kassa Teka Belay, Van Rompaey A, Poesen J, Van Bruyssel S, Deckers J, Amare K. 2014. Spatial analysis of land cover changes in Eastern Tigray (Ethiopia) from 1965 till 2007: are there signs of a forest transition? Land Degradation and Development. DOI: $10.1002 / 1 \mathrm{dr} .2275$

Keyzer M, Sonneveld B, Zod J. 2001. The Effect of Soil Degradation on Agricultural Productivity in Ethiopia: a Non-Parametric Regional Analysis in Economic Policy 
Reform and Sustainable Land Use in LDC's. In: Heerink, $\mathrm{H}$ Van Kenken and Kurpious M (eds) Physica Verlag: pp 269-292.

Kiernan K. 2013. Nature, severity and persistence of geomorphological damage caused by armed conflict. Land Degradation and Development. DOI: 10.1002/1dr.2216

Klepeis P, Vance C. 2003. Neoliberal Policy and Deforestation in Southeastern Mexico: An Assessment of the PROCAMPO Program. Economic Geography 79 (3): 221-240.

Krings T. 2002. A critical review of the Sahel Syndrome Concept from the viewpoint of Political Ecoloy. Geographische Zeitschrift 90 (3-4): 129-141.

Kumasi T, Asenso-Okyere K. 2011. Responding to Land Degradation in the Highlands of Tigray, Northern Ethiopia. IFPRI Discussion Paper 01142, International Food Policy Research Institute.

Lemenih M, Kassa H, Kassie G, Abebaw D, Teka W. 2013. Resettlement and woodland management problems and options: a case study from North-West Ethiopia. Land Degradation and Development. DOI: 10.1002/ldr.2136

Lestrelin G, Giordano M. 2007. Upland development policy, livelihood change and land degradation: interactions from a Laotian village. Land Degradation and Development 18 (1): 55-76.

Machado M, Perez-Gonzalez A, Benito G. 1998. Paleoenvironmental changes during the last 4000 yr in Tigray, Northern Ethiopia. Quaternary Research 49: 312- 321.

Massey D. 1984. Spatial Divisions of Labour: Social Structures and the Structure of production. London: MacMillan.

Mastewal Yami, Wolde Mekuria, Hauser M. 2013. The effectiveness of village bylaws in sustainable management of community-managed exclosures in Northern Ethiopia. Sustainability Science 8 (1): 73-86.

Mattsson J, Rapp A. 1991. The recent droughts in Western Ethiopia and Sudan in a climatic context. AMBIO 20 (5): 172-175.

Meadows D, Meadows D, Randers J, Behrens W. 1972. Limits to growth. Universe Books: New York.

Mekuria A, Vlek P, Denich M. 2012. Application of the caesium-137 technique to soil degradation studies in the Southwestern Highlands of Ethiopia. Land Degradation and Development 23 (5): 456-464.

Melbaa Gadaa. 1988. Oromia: an introduction to the history of the Oromo People. Khartoum, Sudan.

Milas S, Latif JA. 2000. The Political Economy of Complex Emergency and Recovery in Northern Ethiopia. Disasters 24 (4): 363-379. 
Mitiku Haile, Herweg K, Stillhardt B. 2006. Sustainable Land Management - A New Approach to Soil and Water Conservation in Ethiopia. Mekelle, Ethiopia: Land Resources Management and Environmental Protection Department, Mekelle University; Bern, Switzerland: Centre for Development and Environment (CDE), University of Bern, and Swiss National Centre of Competence in Research (NCCR) North-South, 269 pp.

Moore J. 2002. The crisis of feudalism - An environmental history. Organization \& Environment 15 (3): 301-322.

Munro R, Deckers J, Mitiku Haile, Grove A, Poesen J, Nyssen J. 2008. Soil landscapes, land cover change and erosion features of the Central Plateau region of Tigrai, Ethiopia: Photo-monitoring with an interval of 30 years. Catena 75 (1): 55-64.

Nadel S. 1946. Land tenure on the Eritrean plateau. Africa 16 (1-2): 99-109.

Naudts J. 2002. Les Hautes Terres de Tembien, Tigré, Ethiopie; Résistance et limites d'une ancienne civilisation agraire; Conséquences sur la dégradation des terres. Mémoire présenté en vue de l'obtention du Diplôme d'Agronomie Tropicale CNEARC, Montpellier.

Nyssen J, Mitiku Haile, Moeyersons J, Poesen J, Deckers J. 2000. Soil and water conservation in Tigray (Northern Ethiopia): the traditional daget technique and its integration with introduced techniques. Land Degradation and Development 11: 199-208.

Nyssen J, Poesen J, Moeyersons J, Deckers J, Mitiku Haile, Lang A. 2004. Human impact on the environment in the Ethiopian and Eritrean highlands - a state of the art. EarthScience Reviews 64 (3-4): 273-320.

Nyssen J, Poesen J, Veyret-Picot M, Moeyersons J, Mitiku Haile, Deckers J, Dewit J, Naudts J, Kassa Teka, Govers G. 2006. Assessment of gully erosion rates through interviews and measurements: a case study from northern Ethiopia. Earth Surface Processes and Landforms 31 (2): 167-185.

Nyssen J, Mitiku Haile, Naudts J, Munro N, Poesen J, Moeyersons J, Frankl A, Deckers J, Pankhurst R. 2009. Desertification? Northern Ethiopia re-photographed after 140 years. Science of the Total Environment 407 (8): 2749-2755.

Nyssen J, Gezahegne Gebremeskel, Mohamed S, Petrie G, Seghers V, Kiros Meles Hadgu, De Maeyer Ph, Mitiku Haile, Frankl A. 2013. Characterization of recently retrieved aerial photographs of Ethiopia (1935-1941) and their fusion with current remotely sensed imagery for retrospective geomorphological analysis. Geophysical Research Abstracts 15.

Pageau D. 1989. Sécheresses, désertification et famines : la zone sahélienne et l'Ethiopie. Série notes et travaux - Centre Sahel 13; Université Laval, Québec, Canada 29 p. 
Pankhurst R. 1986. The History of Famine and Epidemics in Ethiopia prior to the Twentieth Century. Addis Ababa: Relief and Rehabilitation Commission, 120 pp.

Peet R, Robbins P, Watts M. 2011. Global Political Ecology. Routledge, Oxford.

Robbins P. 2012. Political Ecology: A Critical Introduction. John Wiley \& Sons, Chichester.

Roberts N. 1997. The Holocene, an environmental history. Blackwell Publ, Oxford, UK.

Segele Z, Lamb P, Leslie M. 2009a. Large-scale atmospheric circulation and global sea surface temperature associations with Horn of Africa June-September rainfall. Int. J. Climatol. 29: 1075-1100.

Segele Z, Lamb P, Leslie M. 2009b. Seasonal-to-Interannual Variability of Ethiopia/Horn of Africa Monsoon. Part I: Associations of Wavelet-Filtered Large-Scale Atmospheric Circulation and Global Sea Surface Temperature. J. Climate 22: 3396-3421.

Segers K, Dessein J, Develtere P, Hagberg S, Haylemariam Girmay, Mitiku Haile, Deckers J. 2010. The Role of Farmers and Informal Institutions in Microcredit Programs in Tigray, Northern Ethiopia. Perspectives on Global Development and Technology 9 (34): $520-544$.

Shmelev G. 1991. Soviet agrarian policy past and present. Food Policy 16 (4): 273-276.

Ståhl M. 1974. Ethiopia: political contradictions in agricultural development. Rabén \& Sjögren, Stockholm, 186 p.

Ståhl M. 1990. Environmental degradation and political constraints in Ethiopia Disasters. The journal of disaster studies and management 14: 140-150.

Stocking M. 1995. Soil erosion in developing countries: where geomorphology fears to tread! Catena 25 (1-4): 253-267.

Stringer L, Harris A. 2013. Land degradation in Dolj County, Southern Romania: Environmental changes, impacts and responses. Land Degradation and Development. DOI: $10.1002 / \mathrm{ldr} .2260$

Taddese Girma. 2001. Land Degradation: A Challenge to Ethiopia. Environmental Management 27 (6): 815-824.

Tadesse Kidane-Mariam, 2003. Environmental and Habitat Management: The Case of Ethiopia and Ghana. Environmental Management 31 (3): 313-327.

Tekle Kebrom. 1999. Land degradation problems and their implications for food shortage in south Welo, Ethiopia. Environmental Management 23 (4): 419-427.

Tekle Kebrom, Hedlund L. 2000. Land cover changes between 1958 and 1986 in Kalu district, Southern Wello, Ethiopia. Mountain Research and Development 2: 42-51. 
Tenge A, De Graaff J, Hella J. 2004. Social and economic factors affecting the adoption of soil and water conservation in West Usambara Highlands, Tanzania. Land Degradation and Development 15 (2): 99-114.

Terwilliger V, Zewdu Eshetu, Huang Y, Alexandre M, Umer M, Tsige Gebru. 2011. Local variation in climate and land use during the time of the major kingdoms of the Tigray Plateau in Ethiopia and Eritrea. Catena 85 (2): 130-143.

Thomas P, Ofcansky B, LaVerle B. 1991. Ethiopia: A Country Study. GPO for the Library of Congress, Washington.

Tiffen M, Mortimore M, Gichuki F. 1994. More people less erosion: Environmental recovery in Kenya. London: John Wiley.

UNEP. 1992. World Atlas of Desertification. London: Edward Arnold.

Wøien H. 1995. Deforestation, information and citations: a comment on environmental degradation in Highland Ethiopia. Geojournal 37 (4): 501-512.

Yilma S, Demarée G. 1995. Rainfall variability in the Ethiopian and Eritrean highlands and its links with the Southern Oscillation Index. Journal of Biogeography 22: 945- 952.

Young D, Hinton R. 1996. An introduction to participatory appraisal techniques: sharing experience from China and Nepal London, VSO.

Warren A. 2002. Land degradation is contextual. Land Degradation and Development 13 (6): 449-459.

Zhao G, Mu X, Wen Z, Wang F, Gao P. 2013. Soil erosion, conservation, and ecoenvironment changes in the loess plateau of China. Land Degradation and Development 24 (5): 499-510. 


\section{FIGURES AND TABLES}

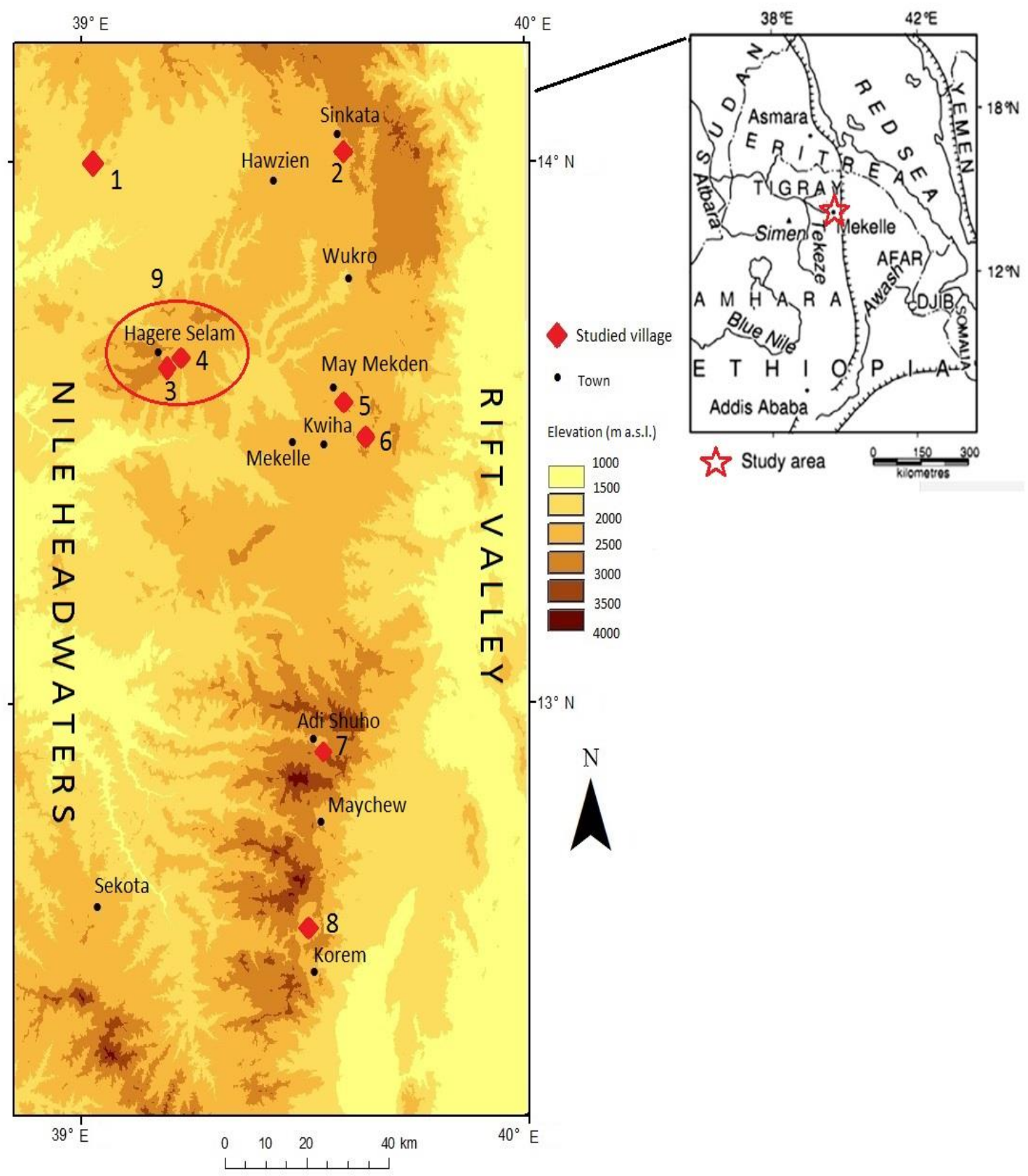

Figure 1: Study area (based on an SRTM image) in the North Ethiopian Highlands (Tigray); and location of the villages for the 2012 interviews: $1=\operatorname{Nebelet}(\mathrm{N}) ; 2=\operatorname{Sinkata}(\mathrm{S}) ; 3=$ Hechi $(\mathrm{H}) ; 4=$ May Ba'ati (MB); 5 = May Mekden (MM); $6=$ Lahama (L); 7 = Adi Shuho (AS); $8=$ Ashenge (A). 9 $=$ the region (red ellipse) where key informants (KI) were interviewed in 2002. 

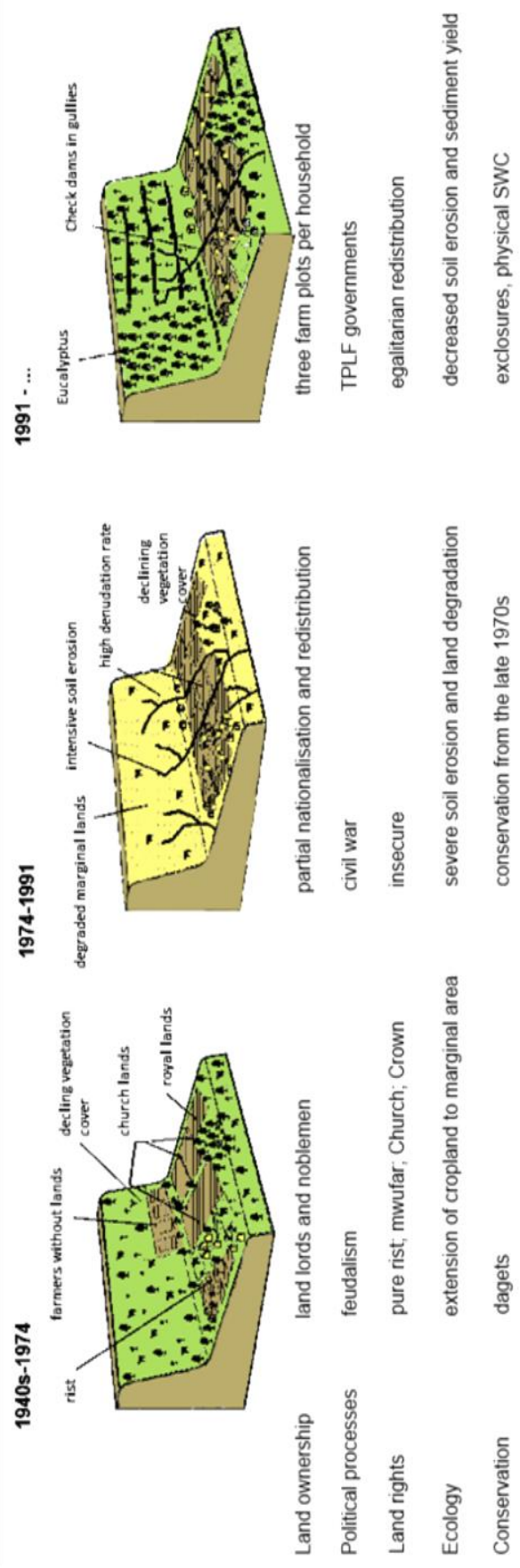

Figure 2. A political-ecologic model of land degradation in the North-Ethiopian Highlands. 

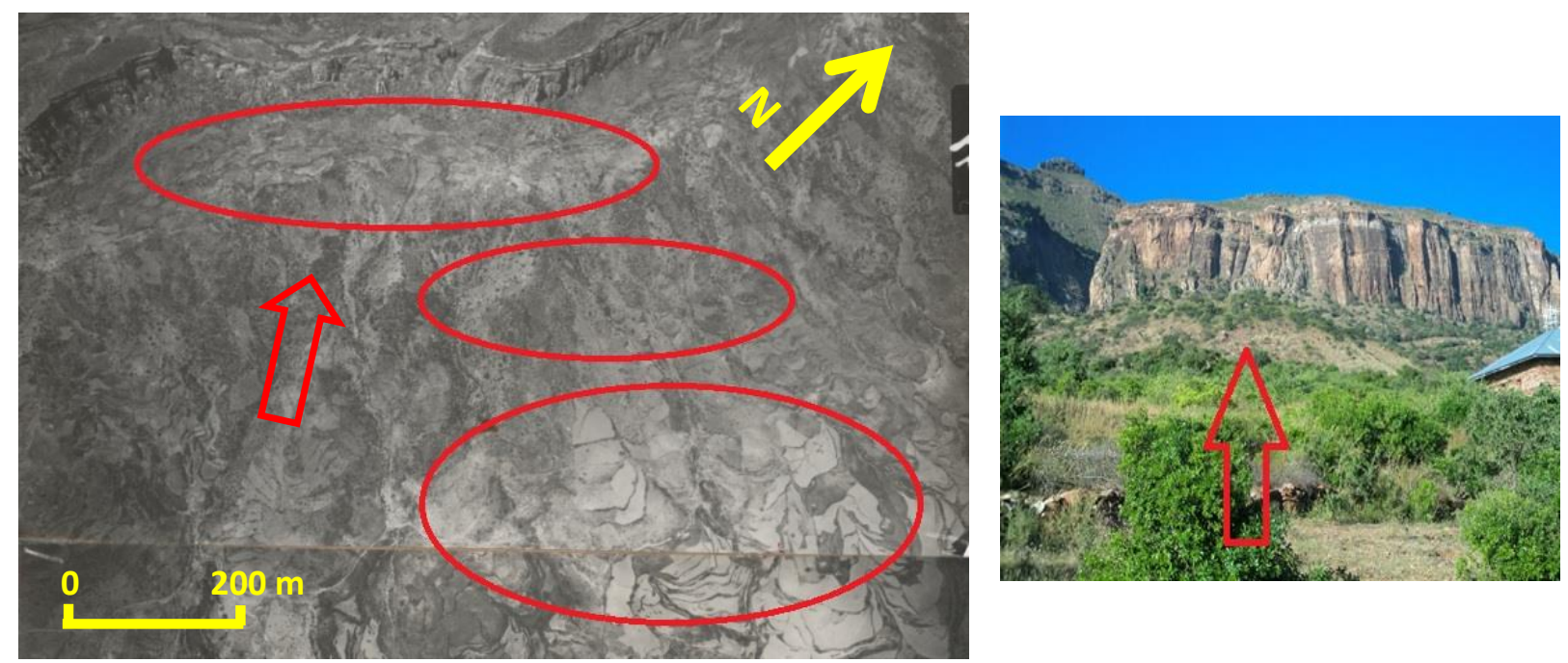

Figure 3: Low-oblique aerial photograph 11-3-74 (taken on 5 October 1935; on the left) shows the marginal farmlands of the poor farmers (upper ellipse), intermediate bare land on steep slopes and the cropland owned by the Church and the rist lands (lower ellipse). The right photograph shows, at the upper (northwestern) part, that the lands of the poor farmers have been abandoned as they have received their share in the lands at the valley bottom (photo taken by S. Lanckriet, 14 December 2012). The red arrow on both photographs indicates identical viewpoint. As the aerial photograph has not been geometrically corrected, the scale bar is only indicative.
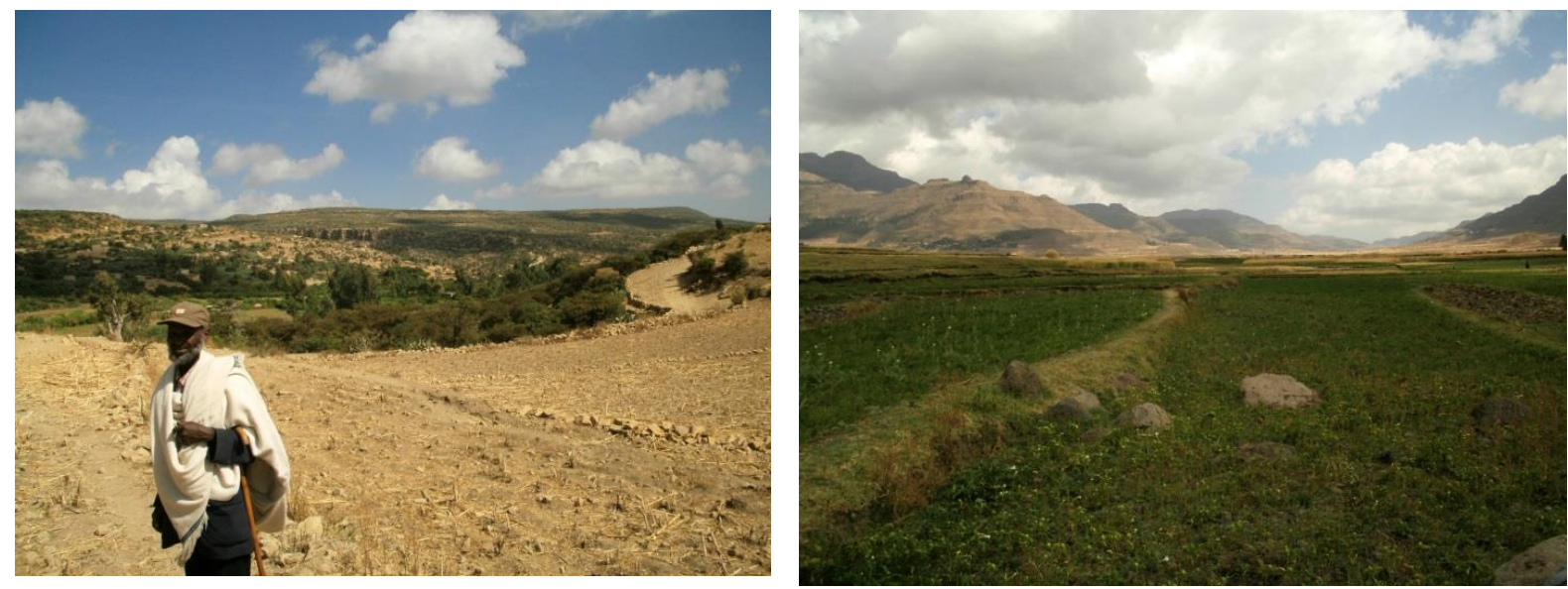

Figure 4: (left) In warm semi-arid Lahama (N13.4993; E39.6122), the low-lying irrigated lands (greenish on the photograph) were owned by the Church during feudal times. However (right) in Adishu (N12.9315; E39.5245), the cold rainy highland marshy lands (greenish on the photograph) were cultivated by poorer farmers during feudal times. 

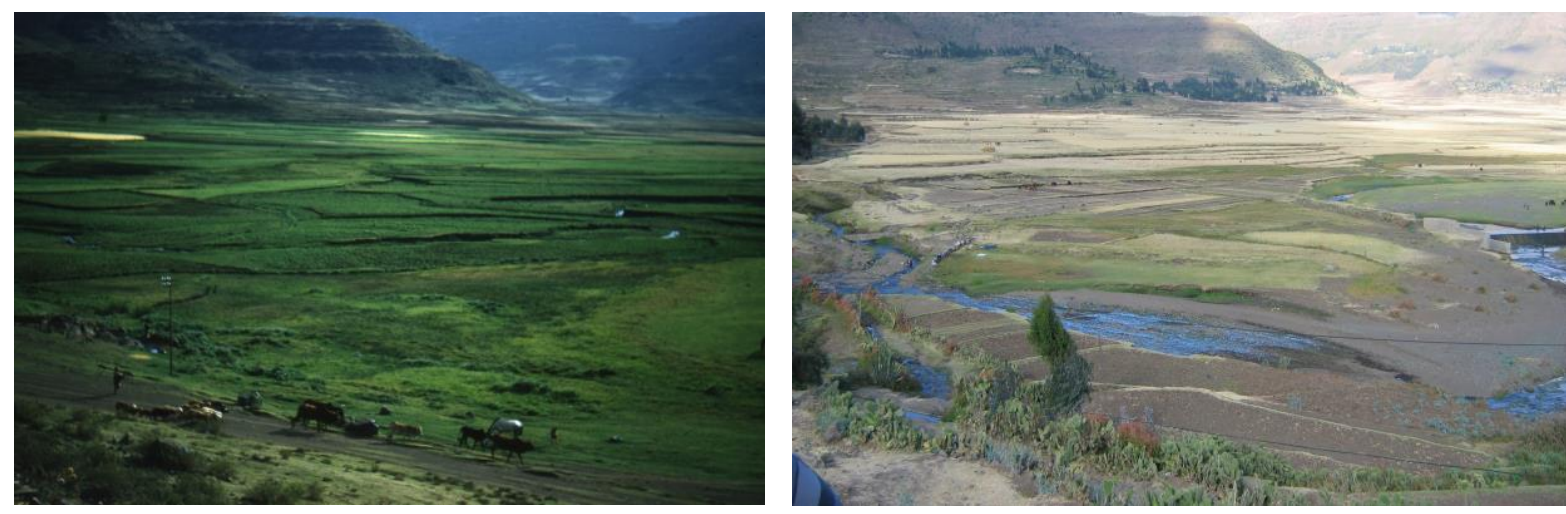

Figure 5: (left) Historical photograph of the Adi Shuho "marsh" during feudal times (1961; A.T. (Dick) Grove); (right) Repeated photograph taken from the same location (2008; Amaury Frankl). These pictures are not in their original proportions.

Table I: Abundance of three feudal land tenancy types in the studied villages, as estimated by the interviewees in 2012.

\begin{tabular}{lll}
\hline Land tenancy & May Mekden & All other villages \\
\hline 'Pure' Rist & $20-40 \%$ & $20-40 \%$ \\
Rist in mwufar (tefurti) & $>40 \%$ & $20-40 \%$ \\
Church or Crown & $<20 \%$ & $20-40 \%$ \\
\hline
\end{tabular}

